\title{
Soil Erosion and Crop Productivity Loss in Palghar and Thane Districts of Maharashtra
}

\author{
S. V. Shejale*, S. B. Nandgude, S. S. Salunkhe, M. A. Phadtare and \\ D. M. Mahale \\ Department of Soil and Water Conservation Engineering, College of Agricultural \\ Engineering and Technology, Dr. B.S.K.K.V., Dapoli- 415 712, Maharashtra, India
}

\begin{abstract}
Present research work was carried out on soil erosion and crop productivity loss in Palghar and Thane districts. The study also describes tolerable soil loss and relationship between top-soil loss and yield loss. The estimated average annual soil loss was $40.45 \mathrm{tha}^{-1} \mathrm{yr}^{-1}$ before adoption of the soil and water conservation measures (by USLE method) and estimated average tolerable soil loss was 9.36 tha ${ }^{1} \mathrm{yr}^{-1}$, for Palghar district. Similarly, the estimated average annual soil loss and tolerable soil loss were found to be $35.89 \mathrm{t} \mathrm{ha}^{-1} \mathrm{yr}^{-1}$ and $9.61 \mathrm{t} \mathrm{ha}^{-1} \mathrm{yr}^{-1}$, respectively for Thane district. The estimated average conservation practice factor $(\mathrm{P})$ factors were obtained as 0.32 for Palghar district and 0.30 for Thane district to bring the soil loss below the tolerable limit. After adoption of soil and water conservation measures, the estimated soil loss were $9.02 \mathrm{t} \mathrm{ha}^{-1} \mathrm{yr}^{-1}$ and $9.38 \mathrm{t} \mathrm{ha}^{-1} \mathrm{yr}^{-1}$ for Palghar and Thane districts, respectively.
\end{abstract}

Keywords: Soil erosion, USLE, tolerable soil loss, RS and GIS.

\section{Introduction}

Soil is one of the limited and irreplaceable resource natural resource and provides beneficial nutrients, water and support to plants. Soil erosion is major global issue specifically for developing countries like India. Hence, soil erosion and consequently land degradation are the major threats to Indian food security and Maharashtra state is not an exception. The quantity of soil erosion per year in Maharashtra is $773.5 \mathrm{M}$ tonnes and 94 per cent of that erosion is water induced.

Assessment of soil erosion is long-term and

*Corresponding author: (Email: shraddhashejale2@gmail.com) expensive process. A number of parametric models have been developed to forecast soil erosion. Universal Soil Loss Equation i.e. USLE (Wischmeier and Smith 1978) is the most popular empirically based model used globally for erosion prediction. However, estimation of soil loss needs to be coupled with soil formation process through pedogenesis. So overall soil erosion and related productivity loss of land is a complex phenomenon involving soil erosion, soil formation, input applications and environmental conditions. It demands multidisciplinary study of all aspects to get realistic view of relationship between soil loss and crop productivity.

For developing suitable soil conservation strategies, knowledge of the prevailing and permissible 
rates of soil erosion is an essential pre-requisite. Tolerable soil loss is a concept developed in the $20^{\text {th }}$ century and it is useful to judge if a soil has potential risk of erosion, productivity loss and off-site damages. The acceptable rate of soil erosion (T-value) is defined as the maximum amount of erosion at which the quality of a soil as a medium for plant growth can be maintained. Quantifying the acceptable soil loss without affecting crop productivity is a major challenge for researchers, planners, conservationists and environmentalists. If the erosion exceeds the value, it adversely affects productivity and must be brought down within the permissible rate to ensure sustainability of a production system. Conservation objectives for soil loss tolerance are based on maintaining a suitable seedbed and nutrient supply in the surface soil, maintaining adequate depth and quality of the root zone, and minimizing unfavourable changes in water availability throughout the soil.

This kind of study is very essential in Konkan region of Maharashtra due to extreme weather conditions and huge loss of soil through run-off. Palghar and Thane are coastal districts of Maharashtra surrounded by the Arabian Sea in the west and the Sahyadri Mountains in the east. Due to high rainfall and hilly terrain both district are facing problem of erosion. However, due to hilly terrain of Sahyadri ranges, data availability or accessibility is scare. The application of Remote Sensing (RS) and Geographical Information System (GIS) is the most suitable technique for coastal resource management. GIS based analysis gives better results and effective strategies for the mitigation of such affected coastal zones.

\section{Materials and Methods}

Studyarea

Palghar and Thane districts were selected as study area. Palghar district is situated between $19^{\circ} 17^{\prime} \mathrm{N}$ and $20^{\circ} 14^{\prime} \mathrm{N}$ latitude and $72^{\circ} 39^{\prime} \mathrm{E}$ and $72^{\circ} 31^{\prime} \mathrm{E}$ longitude. Thane district is situated between $19^{\circ} 19^{\prime} \mathrm{N}$ and $19^{\circ} 23^{\prime} \mathrm{N}$ latitude and $73^{\circ} 19^{\prime} \mathrm{E}$ and $73^{\circ} 30^{\prime} \mathrm{E}$ longitude. The total geographical area of Palghar district is $5,328.3 \mathrm{sq}$. $\mathrm{km}$. associated with average annual rainfall of $2,578 \mathrm{~mm}$ while it is $4,225.10 \mathrm{sq}$. $\mathrm{km}$. (TGA) for Thane district having average annual rainfall of 2,584 $\mathrm{mm}$.

\section{Data Collection}

Tehsil-wise daily rainfall data of Palghar and Thane districts for 1998-2016 were obtained from Department of Agriculture, Maharashtra State. The major soils of the study area are low activity clay soils mostly derived from laterite. The different soil parameters such as sand, silt, clay and organic carbon were collected from the secondary sources (Thawakar 2014). Shuttle Radar Topographic Mission (SRTM) data was used and Land use/ Land cover was prepared using LANDSAT-8 (Date-19/03/2017, winter). Crop data were collected from the District Superintending Agriculture Office (DSAO) of Palghar and Thane districts respectively to obtain the crop cover management factor $(\mathrm{C})$. The bulk densities of different location for all tehsils falling in study area were computed by using pedo-transfer function (PTF) (Kaur et al.2002).

\section{Soil Erosion Model- USLE}

The Universal Soil Loss Equation (Wischmeier and Smith 1978) is being used widely, both within the US and internationally for assessment of soil loss. The equation given by Wischmeier and Smith (1978) is,

$\mathrm{A}=\mathrm{R} * \mathrm{~K} * \mathrm{~L} * \mathrm{~S} * \mathrm{C} * \mathrm{P}$

where, $\mathrm{A}$ is computed soil loss $\left(\mathrm{tha}^{-1} \mathrm{yr}^{-1}\right), \mathrm{R}$ is rainfall erosivity factor ( $\left.\mathrm{MJ} \mathrm{mm} \mathrm{ha}^{-1} \mathrm{~h}^{-1} \mathrm{yr}^{-1}\right), \mathrm{K}$ is soil erodibility factor (t-ha-hr ha ${ }^{-1} \mathrm{MJ}^{-1} \mathrm{~mm}^{-1}$ ), L is slope length factor, $\mathrm{S}$ is slope steepness factor (\%), $\mathrm{C}$ is covermanagement factor and $\mathrm{P}$ is supporting practices factor.

\section{Rainfall Erosivity Factor (R)}

Rainfall erosivity refers to the ability of rainfall to erode the soil particles from an unprotected field. In present study, tehsil-wise daily rainfall data was used for 
estimating erosivity index. Rainfall intensity data was not available for study area and hence the daily precipitation and $\mathrm{EI}_{30}$ data of Wakawali station were used for regression analysis (Yadav and Mhatre 2005). The following equation implies the correlation between daily erosivity index and daily rainfall.

$$
\mathrm{Y}=0.3339 \mathrm{x}^{1.50}
$$

where, $\mathrm{Y}$ is daily erosivity index and $\mathrm{x}$ is daily precipitation. The equation was power in nature and the coefficient of determination obtained was 0.7624 .

\section{Soil Erodibility Factor (K)}

Soil erodibility is the vulnerability or susceptibility of the soil to get eroded. An algebraic approximation of the nomograph that includes soil parameters such as texture, structure, permeability and organic matter content is proposed by Wischmeier and Smith (1978) and Renard et al. (1997).

$\mathrm{K}=\left\{\left[2.1 * 10^{-4} \mathrm{M}^{1.14}(12-\mathrm{a})+3.25(\mathrm{~b}-2)+2.5(\mathrm{c}-\right.\right.$ 3)] $/ 100\} * 0.1317$

Where, $\mathrm{K}$ is soil erodibility factor (t-ha-hr $\left.\mathrm{ha}^{-1} \mathrm{MJ}^{-1} \mathrm{~mm}^{-1}\right), \mathrm{M}$ is $[(\%$ silt $+0.7 * \%$ sand $) *(100-\%$ clay)], a is organic matter content, $b$ is structure of the soil and $\mathrm{c}$ is permeability of the soil.

Based on soil parameters, tehsil-wise Soil erodibility factor $(\mathrm{K})$ factor values for different locations of the study area were calculated by using Eqn. 3 .

\section{Topographic Factor (LS)}

Topographic factor (LS) in USLE accounts for the effect of topography on sheet and rill erosion. The two parameters that constitute the topographic factor are slope gradient (S) and slope length factor (L) and can be estimated from a digital elevation model (DEM). The relationship between the slope steepness in percentages $(\mathrm{Sp})$ and slope length in meters (L) were used to generate slope length map. It is given by

$$
\mathrm{L}=0.4 * \mathrm{Sp}+40
$$

Where, $\mathrm{L}=$ Slope length in meters and $\mathrm{Sp}=$ Slope steepness in percentage. Using this equation, the map of slope length was prepared.

Although $\mathrm{L}$ and $\mathrm{S}$ factors were determined separately, the procedure has been further simplified by combining the $\mathrm{L}$ and $\mathrm{S}$ factors together and considering the two as a single topographic factor (LS) (Wischmeier and Smith 1965). The LS factor layer was generated for, I. Slope steepness less up to $21 \%$, the equation modified by Wischmeier and Smith (1978) was used which is, $\mathrm{LS} 1=(\mathrm{L} / 22.13)^{\mathrm{m}} *\left(65.41 \sin ^{2} \theta+4.56 \sin \theta+0.065\right)$ ....(5)

where, LS1 is the slope length and gradient factor and $\theta$ is angle of the slope.

II. Slope steepness of $21 \%$ or more, the equation used, which is given by

$\mathrm{LS} 2=(\mathrm{L} / 22.13)^{0.7} *\left(6.432 * \sin \left(\theta^{0.79}\right) * \cos (\theta)\right)$ ....(6)

where, LS2 is the slope length and gradient factor, $\theta$ is angle of the slope and $L$ is slope length in metre. The slope maps (both in per cent and degree ) were prepared from the SRTM DEM. Based on these slope maps, slope length (L) and slope gradient (S) maps and finally a layer of LS factor were generated for Palghar and Thane districts.

\section{Crop Management Factor $(C)$}

Crop management factor is the ratio of soil loss from a cropped land under specific condition to soil loss from a continuous fallow land, provided that soil type, slope and rainfall conditions are identical. LANDSAT- 8 data were used to find out the various land use classes. Weighed value of $\mathrm{C}$ based, on cropping pattern, was calculated for different classes and $\mathrm{C}$ factor was prepared.

\section{Conservation Practice Factor $(P)$}

It may be defined as the ratio of soil loss under a given conservation practice to the soil loss from up and down the slope. P factor assigned as 1 for the Palghar and Thane districts as it were untreated. 


\section{Estimation of tolerable soil loss}

The tolerable soil loss (T-value) is defined as the amount of soil that could be lost without a decline of fertility, thereby maintaining crop productivity indefinitely (Smith 1941). The loss of crop yield due to loss of top soil may be compensated by the formation of new soil through pedogenesis. Topsoil formation at the rate of $1 \mathrm{~mm}^{-1}$ year was equivalent to an annual addition of 13.3 tonnes $^{-1}$ ha, taking into account the weight of a hectare furrow slice $\left(15 \mathrm{~cm}\right.$ depth) soil as $2.2 \times 10^{6} \mathrm{~kg}$ (Bhattacharya et al. 2007). Since, study area represents a tropical wet climate; the soil formation rate of $2.0 \mathrm{~mm}$ should be equivalent to an annual addition of $(2.2 \mathrm{x}$ $\left.10^{6} / 150\right) \times 2.0=29$ tha $^{-1}$ soil.
In the present study, the relationship between topsoil loss and yield loss was estimated on the basis of available data, soil has been classified in terms of their susceptibility to productivity loss of topsoil. These ranking of susceptibility of the soils were related to actual yield losses, and by input levels which were calculated by set of linear equations (Table 1).

There were two relations used to estimate the tolerable soil loss

1. Relation between crop yield and loss of topsoil.

2. Proportion of land that can be allow to make the soil shallower at least by one soil depth class over a specified time period.

Table 1. Relationship between topsoil loss and yield loss

\begin{tabular}{|c|c|}
\hline Soil susceptibility & Input level \\
\hline Least susceptible & $\begin{array}{l}\text { Low } \\
\text { Intermediate } \\
\text { High }\end{array}$ \\
\hline Intermediate susceptible & $\begin{array}{l}\text { Low } \\
\text { Intermediate } \\
\text { High }\end{array}$ \\
\hline Most susceptible & $\begin{array}{l}\text { Low } \\
\text { Intermediate } \\
\text { High }\end{array}$ \\
\hline \multicolumn{2}{|l|}{ (Bhattacharya et al. 2007) } \\
\hline \multicolumn{2}{|c|}{ Relationship between loss of yield and loss of topsoil } \\
\hline \multicolumn{2}{|c|}{$\begin{array}{l}\text { The tolerable loss rate for a given soil unit and specified } \\
\text { amount and time scale of yield reduction was calculated } \\
\text { by following equation (Bhattacharya et al. 2007) }\end{array}$} \\
\hline \multirow{2}{*}{\multicolumn{2}{|c|}{$T L=\frac{l \mathrm{Rm}}{T}$}} \\
\hline & \\
\hline \multicolumn{2}{|c|}{$\begin{array}{l}\text { where, TL is tolerable soil loss rate }\left(\mathrm{t} \mathrm{ha}^{-1} \mathrm{yr}^{-1}\right), \mathrm{Ra} \text { is the } \\
\text { acceptable yield reduction }(\%), \mathrm{Rm} \text { is the yield reduction } \\
(\%) \text { at the given input level when the effective top soil is } \\
\text { lost, BD is bulk density of soil }\left(\mathrm{Mg} \mathrm{m}^{-3}\right), \mathrm{D} \text { is the depth of } \\
\text { effective topsoil }(\mathrm{cm}) \text { and } \mathrm{T} \text { is time in years over which } \\
\text { reduction is acceptable. }\end{array}$} \\
\hline
\end{tabular}

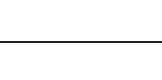

Yield loss $(\mathbf{y} \%)$
$y=1.0 x$
$y=0.6 x$
$y=0.2 x$
$y=2.0 x$
$y=1.2 x$
$y=0.4 x$
$y=7.0 x$
$y=5.0 x$
$y=3.0 x$

$\mathrm{x}=$ topsoil depth $(\mathrm{cm})$

In present study the tolerable loss rate $\left(\mathrm{tha}^{-1} \mathrm{yr}^{-1}\right)$ for each tehsil of Palghar and Thane districts were calculated (Eqn. 7) over a specified period of 100 years.

The estimation of the effect of soil depth reduction is based on the assumption that there is no significant loss of productivity until the soil becomes so shallow that moisture becomes a limiting factor.

To calculate the soil losses, soil-depth reduction may be measured in terms of proportion of the soils in an area that was shallower than a given depth due to erosion. The rate of soil loss is related to the proportion of land whose soil has become shallower than a specified depth by the following equation,

$$
P=\frac{S L^{*} T}{B D^{*} D}
$$


where, $\mathrm{P}$ is the proportion of land downgraded to at least the next depth class $(\%), \mathrm{SL}$ is the soil loss $\left(\mathrm{t} \mathrm{ha}^{-1} \mathrm{yr}^{-1}\right)$, $\mathrm{T}$ is the time (years).

Estimation of bulk density using Pedotransfer function (PTF)

Estimation of tolerable soil loss depends on bulk density so it was determined by the indirect method. Based on input data, PTF developed by Kaur et al. (2002) was used for estimation of bulk density.

The PTF was validated by estimating the bulk density of the soils for Sindhudurg district and found to be satisfactory with actual values of soil bulk density. Bulk density $\left(\mathrm{Mg} \mathrm{m}^{-3}\right)=\exp \{0.313-0.191$ OC + $0.02102 *$ Clay $-0.000476 *$ (Clay) ${ }^{2}-0.00432 *$ Silt $\} \ldots$ (9)

\section{Results and Discussion}

Rainfall Erosivity Factor (R)

The average annual erosivity obtained for Palghar and Thane districts were 7,374.21 MJ-mm ha' ${ }^{1} \mathrm{hr}^{-1} \mathrm{yr}^{-1}$ and 6889.41 MJ-mm ha ${ }^{-1} \mathrm{hr}^{-1} \mathrm{yr}^{-1}$, respectively. By using these annual erosivity values R-maps of Palghar and Thane districts were prepared (Figs. 1 and 2).

\section{Soil Erodibility Factor (K)}

The soil erodibility factor were calculated for 35 villages of Palghar district and 25 villages of Thane

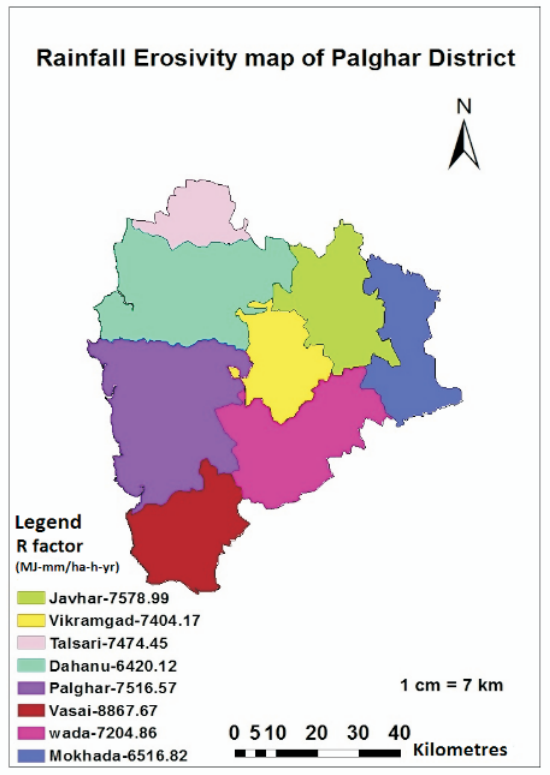

Fig. 1 Rainfall erosivity map of Palghar district district. The different soil parameters such as sand, silt, clay and organic carbon were collected from elsewhere (Thawakar 2014). Soil erodibility factor for Palghar and Thane districts were found to be in the range of 0.020 to 0.048 t-ha-hr ha ${ }^{-1} \mathrm{MJ}^{-1} \mathrm{~mm}^{-1}$ and 0.020 to $0.067 \mathrm{t}$-ha-hr ha ${ }^{1} \mathrm{MJ}^{-1} \mathrm{~mm}^{-1}$, respectively. Accordingly, soil erodibility factor maps of Palghar and Thane districts were prepared (Figs. 3 and 4).

\section{Topographic Factor (LS)}

The value of LS factor for Palghar district was found to be in the range of 1.92-4.19 whereas the value of LS factor for Thane district was found to be in the range of 1.92-4.19. Topographic factor maps of Palghar and Thane districts were prepared (Figs. 5 and 6).

\section{Crop Management Factor $(C)$}

Five land use classes forest, agricultural land, water body, barren land and urban area Crop management factor $(\mathrm{C})$ value was ranging from 0.023 to 0.14 for Palghar district and 0.023 to 0.12 for Thane district. Map of $\mathrm{C}$ factor for Palghar and Thane districts were prepared (Figs. 7 and 8).

\section{Conservation Practice Factor $(P)$}

The value of $\mathrm{P}$ factor was considered as 1 for Palghar and Thane districts as it was untreated.

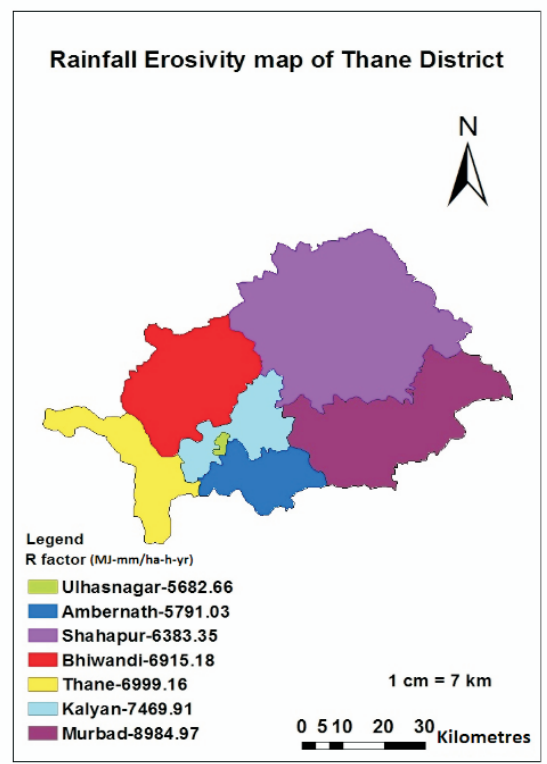

Fig. 2 Rainfall erosivity map of Thane district 


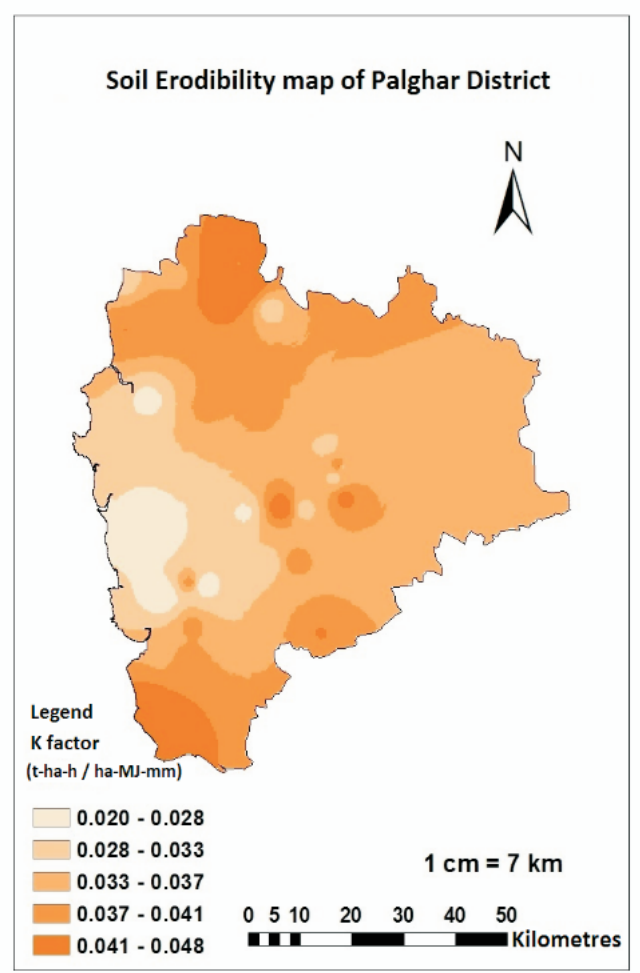

Fig. 3 Soil erodibility map of Palghar district

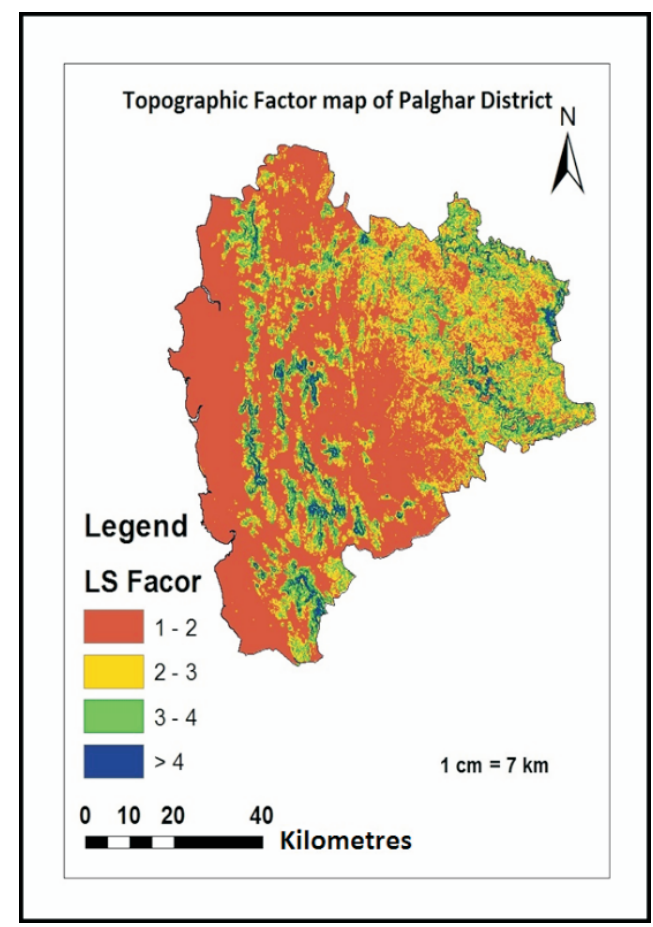

Fig. 5 Topographic factor map of Palghar district

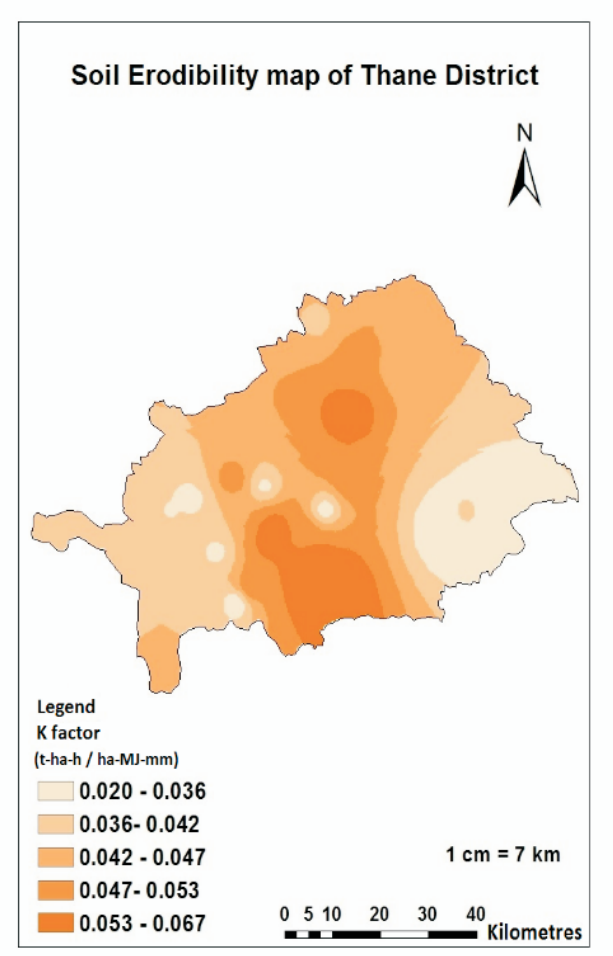

Fig. 4 Soil erodibility map of Thane district

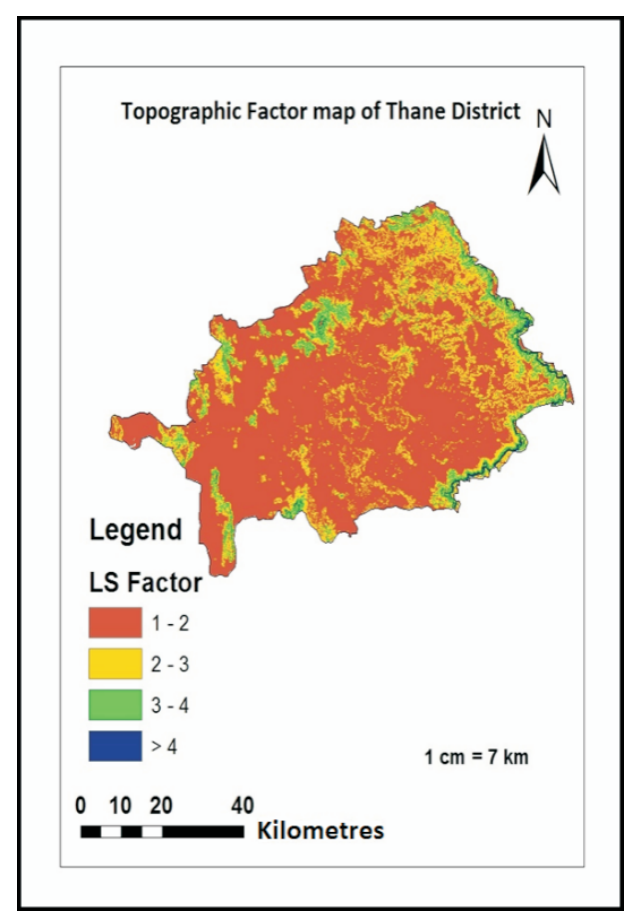

Fig. 6 Topographic factor map of Thane district 


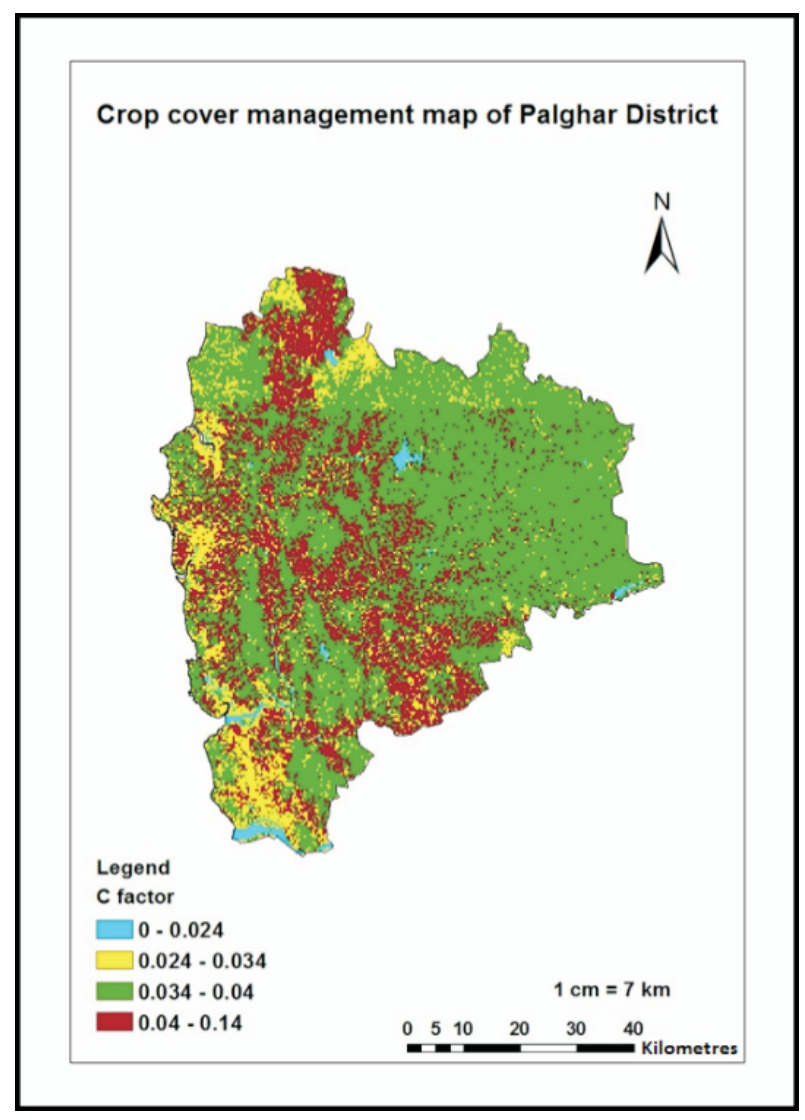

Fig. 7 Crop cover management map of Palghar district Average Annual Soil Loss using USLE

All the layers viz. R, K, LS, C and $\mathrm{P}$ were generated in GIS and were overlaid to estimate the annual soil loss. The average annual soil loss estimated for

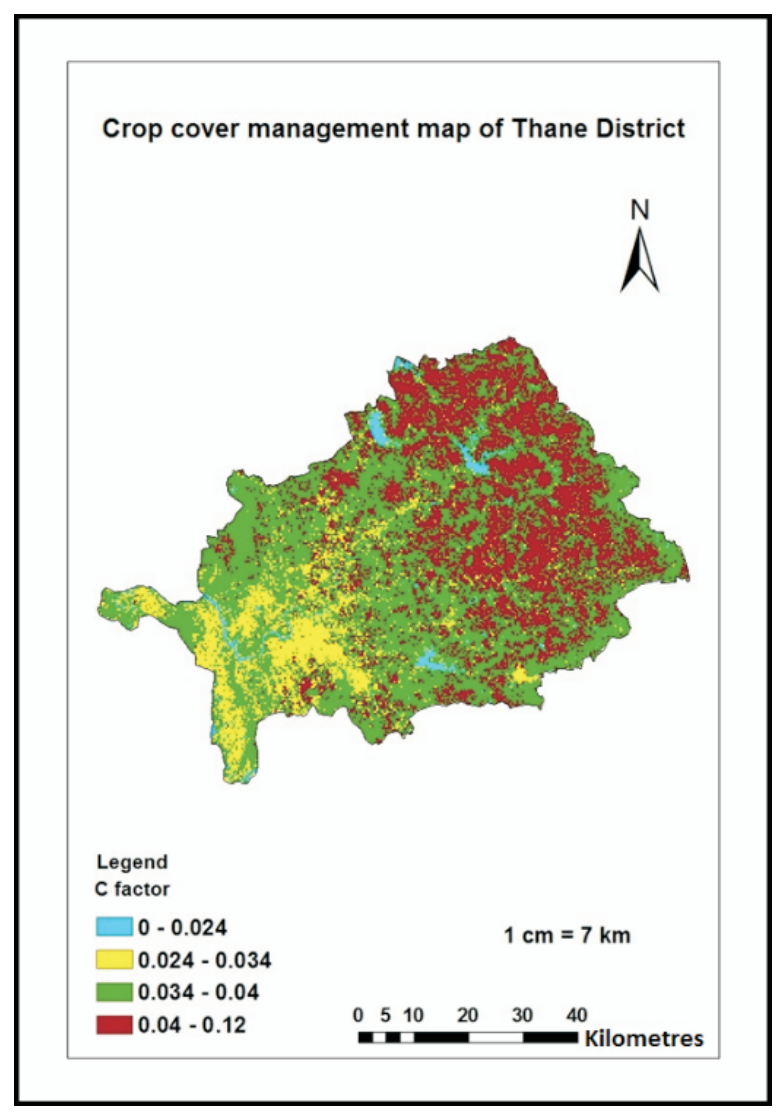

Fig. 8 Crop cover management map of Thane district

Palghar and Thane districts were $40.45 \mathrm{t} \mathrm{ha}^{-1} \mathrm{yr}^{-1}$ and $35.89 \mathrm{t} \mathrm{ha}^{-1} \mathrm{yr}^{-1}$, respectively (Table 2). The map of average annual soil loss of Palghar and Thane districts are shown in figs. 9 and. 10.

Table 2. Area under different classes of soil erosion before conservation measures for Palghar and Thane districts

\begin{tabular}{lccccc}
\hline \multirow{2}{*}{ Soil erosion class } & \multirow{2}{*}{$\begin{array}{c}\text { Soil loss } \\
\left(\mathbf{t ~ h a}^{-\mathbf{1}} \mathbf{~} \mathbf{r}^{\mathbf{- 1}} \mathbf{)}\right.\end{array}$} & \multicolumn{2}{c}{ Palghar District } & \multicolumn{2}{c}{ Thane District } \\
\cline { 3 - 6 } & & Area (ha) & \% Area & Area (ha) & \% Area \\
\hline Slight & $0-5$ & 9378.09 & 1.77 & 12264.55 & 2.92 \\
Moderate & $5-10$ & 21381.82 & 4.04 & 26154.51 & 6.24 \\
Moderately severe & $10-20$ & 48625.69 & 9.20 & 76167.39 & 18.16 \\
Severe & $20-40$ & 251709.23 & 47.60 & 170514.6 & 40.66 \\
Very severe & $40-80$ & 171054.44 & 32.35 & 121478.7 & 28.97 \\
Extremely severe & $>80$ & 26642.43 & 5.04 & 12800.28 & 3.05 \\
\hline
\end{tabular}




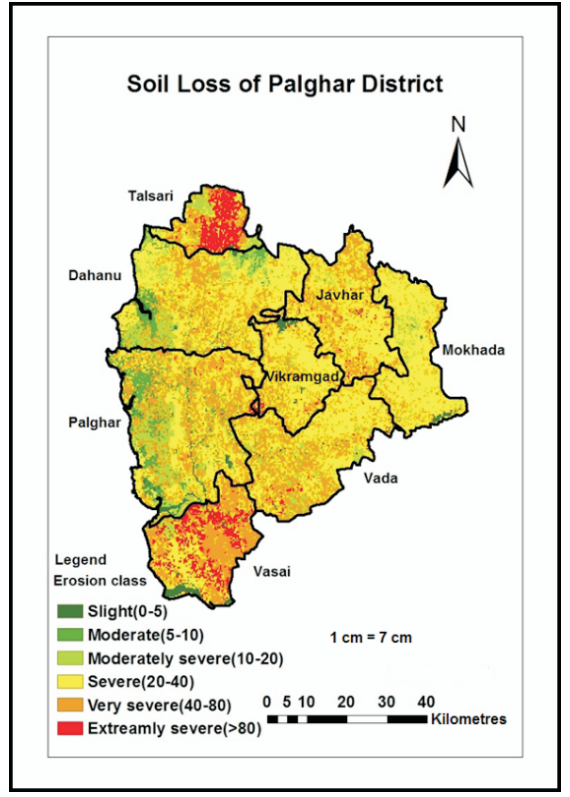

Fig. 9 Average annual soil loss map of Palghar district before conservation measures

\section{Tolerable soil loss}

Tolerable soil loss was estimated (i) through value of yield loss that can be tolerated or (ii) the proportion of land (per cent) that can be allowed to make the depth of soil shallower at least by one soil depth class over a specified time period.

The values of bulk density of the soils for all (Table 3) tehsils of Palghar and Thane districts were estimated using the PTF proposed by Kaur et al. (2002).

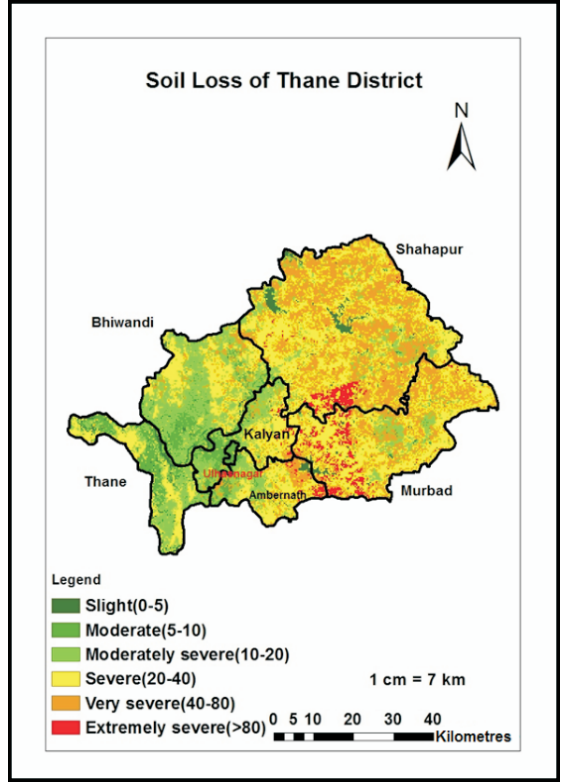

Fig. 10 Average annual soil loss map of Thane district before conservation measures

The average soil bulk densities estimated for Palghar and Thane districts were $1.25 \mathrm{Mg} \mathrm{m}^{-3}$ and $1.28 \mathrm{Mg} \mathrm{m}^{-3}$, respectively

The tolerable soil losses for each tehsil of Palghar and Thane districts were estimated over a specified time period of 100 years. The tolerable soil loss calculated through the second method (Eqn.8) for Palghar and Thane districts (Table 4 and 5) often produces a lower estimate (Table 6 and 7) than first method (Eqn. 7).

Table 3. Bulk density of each tehsils of Palghar and Thane districts

\begin{tabular}{ccc}
\hline Sr. No. & Tehsil Name & Bulk density $\left(\mathbf{M g ~ m}^{-3}\right)$ \\
\hline 1. & Palghar District & 1.20 \\
2. & Talsari & 1.22 \\
3. & Dahanu & 1.20 \\
4. & Palghar & 1.3 \\
5. & Vasai & 1.25 \\
6. & Vada & 1.28 \\
7. & Javhar & 1.23 \\
8. & Vikramgad & 1.28 \\
& Mokhada & 1.25 \\
1. & Thane District & 1.25 \\
2. & Thane & 1.27 \\
3. & Bhiwandi & 1.27 \\
4. & Shahapur & 1.32 \\
5. & Murbad & 1.29 \\
6. & Kalyan & 1.32 \\
7. & Ambernath & \\
\hline
\end{tabular}


Table 4. Proportion of land downgraded from given classes due to soil loss in each tehsil of Palghar district (over a 100 year period)

\section{Talsari and Palghar}

\begin{tabular}{|c|c|c|c|c|c|c|}
\hline \multirow[t]{2}{*}{ Soil depth class and change $(\mathrm{cm})$} & \multicolumn{6}{|c|}{$\begin{array}{l}\text { Amount of soil lost (\% of class) at erosion rates } \\
\qquad\left(\mathrm{t} \mathrm{ha}^{-1} \mathrm{yr}^{-1}\right)\end{array}$} \\
\hline & 5 & 10 & 25 & $\mathbf{5 0}$ & 75 & 100 \\
\hline From shallow $(<25 \mathrm{~cm})$ to bedrock $(0)$ & 16.67 & 33.33 & 83.33 & & & \\
\hline From moderately shallow $(25-50 \mathrm{~cm})$ to shallow $(<25 \mathrm{~cm})$ & 16.67 & 33.33 & 83.33 & & & \\
\hline $\begin{array}{l}\text { From moderately deep }(50-100 \mathrm{~cm}) \text { to moderately shallow } \\
(25-50 \mathrm{~cm})\end{array}$ & 5.56 & 11.11 & 27.78 & 55.56 & 83.33 & 100 \\
\hline From deep $(100-150 \mathrm{~cm})$ to moderately deep $(50-100 \mathrm{~cm})$ & 3.33 & 6.67 & 16.67 & 33.33 & 50.00 & 66.67 \\
\hline From very deep $(>150 \mathrm{~cm})$ to deep $(100-150 \mathrm{~cm})$ & 2.38 & 4.76 & 11.90 & 23.81 & 35.71 & 47.62 \\
\hline \multicolumn{7}{|c|}{ Dahanu } \\
\hline \multirow[t]{2}{*}{ Soil depth class and change $(\mathrm{cm})$} & \multicolumn{6}{|c|}{$\begin{array}{l}\text { Amount of soil lost (\% of class) at erosion rates } \\
\qquad\left(\mathrm{t} \mathrm{ha}^{-1} \mathrm{yr}^{-1}\right)\end{array}$} \\
\hline & 5 & 10 & 25 & $\mathbf{5 0}$ & 75 & 100 \\
\hline From shallow $(<25 \mathrm{~cm})$ to bedrock $(0)$ & 16.39 & 32.79 & 81.97 & & & \\
\hline From moderately shallow $(25-50 \mathrm{~cm})$ to shallow $(<25 \mathrm{~cm})$ & 16.39 & 32.79 & 81.97 & & & \\
\hline $\begin{array}{l}\text { From moderately deep }(50-100 \mathrm{~cm}) \text { to moderately shallow } \\
(25-50 \mathrm{~cm})\end{array}$ & 5.46 & 10.93 & 27.32 & 54.64 & 81.97 & 100 \\
\hline From deep $(100-150 \mathrm{~cm})$ to moderately deep $(50-100 \mathrm{~cm})$ & 3.28 & 6.56 & 16.39 & 32.79 & 49.18 & 65.57 \\
\hline From very deep $(>150 \mathrm{~cm})$ to deep $(100-150 \mathrm{~cm})$ & 2.34 & 4.68 & 11.71 & 23.42 & 35.13 & 46.84 \\
\hline \multicolumn{7}{|c|}{ Vasai } \\
\hline \multirow[t]{2}{*}{ Soil depth class and change (cm) } & \multicolumn{6}{|c|}{$\begin{array}{l}\text { Amount of soil lost (\% of class) at erosion rates } \\
\qquad\left(\mathrm{t} \mathrm{ha}^{-1} \mathrm{yr}^{-1}\right)\end{array}$} \\
\hline & 5 & 10 & 25 & 50 & 75 & 100 \\
\hline From shallow $(<25 \mathrm{~cm})$ to bedrock $(0)$ & 15.38 & 30.77 & 76.92 & & & \\
\hline From moderately shallow $(25-50 \mathrm{~cm})$ to shallow $(<25 \mathrm{~cm})$ & 15.38 & 30.77 & 76.92 & & & \\
\hline $\begin{array}{l}\text { From moderately deep }(50-100 \mathrm{~cm}) \text { to moderately shallow } \\
(25-50 \mathrm{~cm})\end{array}$ & 5.13 & 10.26 & 25.64 & 51.28 & 76.92 & 100 \\
\hline From deep $(100-150 \mathrm{~cm})$ to moderately deep $(50-100 \mathrm{~cm})$ & 3.08 & 6.15 & 15.38 & 30.77 & 46.15 & 61.54 \\
\hline From very deep $(>150 \mathrm{~cm})$ to deep $(100-150 \mathrm{~cm})$ & 2.20 & 4.40 & 10.99 & 21.98 & 32.97 & 43.96 \\
\hline \multicolumn{7}{|c|}{ Vada } \\
\hline \multirow[t]{2}{*}{ Soil depth class and change (cm) } & \multicolumn{6}{|c|}{$\begin{array}{l}\text { Amount of soil lost (\% of class) at erosion rates } \\
\left(\mathrm{t} \mathrm{ha}^{-1} \mathrm{yr}^{-1}\right)\end{array}$} \\
\hline & 5 & 10 & 25 & 50 & 75 & 100 \\
\hline From shallow $(<25 \mathrm{~cm})$ to bedrock $(0)$ & 16.39 & 32.79 & 81.97 & & & \\
\hline From moderately shallow $(25-50 \mathrm{~cm})$ to shallow $(<25 \mathrm{~cm})$ & 16.39 & 32.79 & 81.97 & & & \\
\hline $\begin{array}{l}\text { From moderately deep }(50-100 \mathrm{~cm}) \text { to moderately shallow } \\
(25-50 \mathrm{~cm})\end{array}$ & 5.46 & 10.93 & 27.32 & 54.64 & 81.97 & 100.00 \\
\hline From deep $(100-150 \mathrm{~cm})$ to moderately deep $(50-100 \mathrm{~cm})$ & 3.28 & 6.56 & 16.39 & 32.79 & 49.18 & 65.57 \\
\hline From very deep $(>150 \mathrm{~cm})$ to deep $(100-150 \mathrm{~cm})$ & 2.34 & 4.68 & 11.71 & 23.42 & 35.13 & 46.84 \\
\hline
\end{tabular}




\begin{tabular}{|c|c|c|c|c|c|c|}
\hline \multicolumn{7}{|c|}{ Javhar and Mokhada } \\
\hline \multirow[t]{2}{*}{ Soil depth class and change $(\mathrm{cm})$} & \multicolumn{6}{|c|}{$\begin{array}{l}\text { Amount of soil lost (\% of class) at erosion rates } \\
\qquad\left(\mathrm{t} \mathrm{ha}^{-1} \mathrm{yr}^{-1}\right)\end{array}$} \\
\hline & 5 & 10 & 25 & 50 & 75 & 100 \\
\hline From shallow $(<25 \mathrm{~cm})$ to bedrock $(0)$ & 15.63 & 31.25 & 78.13 & & & \\
\hline From moderately shallow $(25-50 \mathrm{~cm})$ to shallow $(<25 \mathrm{~cm})$ & 15.63 & 31.25 & 78.13 & & & \\
\hline $\begin{array}{l}\text { From moderately deep }(50-100 \mathrm{~cm}) \text { to moderately shallow } \\
(25-50 \mathrm{~cm})\end{array}$ & 5.21 & 10.42 & 26.04 & 52.08 & 78.13 & 100.00 \\
\hline From deep $(100-150 \mathrm{~cm})$ to moderately deep $(50-100 \mathrm{~cm})$ & 3.13 & 6.25 & 15.63 & 31.25 & 46.88 & 62.50 \\
\hline From very deep $(>150 \mathrm{~cm})$ to deep $(100-150 \mathrm{~cm})$ & 2.23 & 4.46 & 11.16 & 22.32 & 33.48 & 44.64 \\
\hline \multicolumn{7}{|c|}{ Vikramgad } \\
\hline \multirow{2}{*}{ Soil depth class and change (cm) } & \multicolumn{6}{|c|}{$\begin{array}{c}\text { Amount of soil lost (\% of class) at erosion rates } \\
\left(\mathrm{t} \mathrm{ha}^{-1} \mathrm{yr}^{-1}\right)\end{array}$} \\
\hline & 5 & 10 & 25 & $\mathbf{5 0}$ & 75 & 100 \\
\hline From shallow $(<25 \mathrm{~cm})$ to bedrock $(0)$ & 16.26 & 32.52 & 81.30 & & & \\
\hline From moderately shallow $(25-50 \mathrm{~cm})$ to shallow $(<25 \mathrm{~cm})$ & 16.26 & 32.52 & 81.30 & & & \\
\hline $\begin{array}{l}\text { From moderately deep }(50-100 \mathrm{~cm}) \text { to moderately shallow } \\
(25-50 \mathrm{~cm})\end{array}$ & 5.42 & 10.84 & 27.10 & 54.20 & 81.30 & 100.00 \\
\hline From deep $(100-150 \mathrm{~cm})$ to moderately deep $(50-100 \mathrm{~cm})$ & 3.25 & 6.50 & 16.26 & 32.52 & 48.78 & 65.04 \\
\hline From very deep $(>150 \mathrm{~cm})$ to deep $(100-150 \mathrm{~cm})$ & 2.32 & 4.65 & 11.61 & 23.23 & 34.84 & 46.46 \\
\hline
\end{tabular}

Table 5. Proportion of land downgraded from given classes due to soil loss in each tehsil of Thane district (over a period of 100 years)

\begin{tabular}{|c|c|c|c|c|c|c|}
\hline \multicolumn{7}{|c|}{ Thane and Bhiwandi } \\
\hline \multirow{2}{*}{ Soil depth class and change $(\mathrm{cm})$} & \multicolumn{6}{|c|}{$\begin{array}{c}\text { Amount of soil lost (\% of class) at erosion rates } \\
\left(\mathrm{t} \mathrm{ha}^{-1} \mathrm{yr}^{-1}\right)\end{array}$} \\
\hline & 5 & 10 & 25 & $\mathbf{5 0}$ & 75 & 100 \\
\hline From shallow $(<25 \mathrm{~cm})$ to bedrock $(0)$ & 16.00 & 32.00 & 80.00 & & & \\
\hline From moderately shallow $(25-50 \mathrm{~cm})$ to shallow $(<25 \mathrm{~cm})$ & 16.00 & 32.00 & 80.00 & & & \\
\hline $\begin{array}{l}\text { From moderately deep }(50-100 \mathrm{~cm}) \text { to moderately shallow } \\
(25-50 \mathrm{~cm})\end{array}$ & 5.33 & 10.67 & 26.67 & 53.33 & 80.00 & 100.00 \\
\hline From deep $(100-150 \mathrm{~cm})$ to moderately deep $(50-100 \mathrm{~cm})$ & 3.20 & 6.40 & 16.00 & 32.00 & 48.00 & 64.00 \\
\hline From very deep $(>150 \mathrm{~cm})$ to deep $(100-150 \mathrm{~cm})$ & 2.29 & 4.57 & 11.43 & 22.86 & 34.29 & 45.71 \\
\hline \multicolumn{7}{|c|}{ Shahapur and Murbad } \\
\hline \multirow{2}{*}{ Soil depth class and change $(\mathrm{cm})$} & \multicolumn{6}{|c|}{$\begin{array}{l}\text { Amount of soil lost (\% of class) at erosion rates } \\
\qquad\left(\mathrm{t} \mathrm{ha}^{-1} \mathrm{yr}^{-1}\right)\end{array}$} \\
\hline & 5 & 10 & 25 & 50 & 75 & 100 \\
\hline From shallow $(<25 \mathrm{~cm})$ to bedrock $(0)$ & 15.75 & 31.50 & 78.74 & & & \\
\hline From moderately shallow $(25-50 \mathrm{~cm})$ to shallow $(<25 \mathrm{~cm})$ & 15.75 & 31.50 & 78.74 & & & \\
\hline $\begin{array}{l}\text { From moderately deep }(50-100 \mathrm{~cm}) \text { to moderately shallow } \\
(25-50 \mathrm{~cm})\end{array}$ & 5.25 & 10.50 & 26.25 & 52.49 & 78.74 & 100.00 \\
\hline From deep $(100-150 \mathrm{~cm})$ to moderately deep $(50-100 \mathrm{~cm})$ & 3.15 & 6.30 & 15.75 & 31.50 & 47.24 & 62.99 \\
\hline From very deep $(>150 \mathrm{~cm})$ to deep $(100-150 \mathrm{~cm})$ & 2.25 & 4.50 & 11.25 & 22.50 & 33.75 & 44.99 \\
\hline
\end{tabular}




\section{Kalyan and Ulhasnagar}

\begin{tabular}{|c|c|c|c|c|c|c|}
\hline \multirow[t]{2}{*}{ Soil depth class and change $(\mathrm{cm})$} & \multicolumn{6}{|c|}{$\begin{array}{l}\text { Amount of soil lost (\% of class) at erosion rates } \\
\qquad\left(\mathrm{t} \mathrm{ha}^{-1} \mathrm{yr}^{-1}\right)\end{array}$} \\
\hline & 5 & 10 & 25 & $\mathbf{5 0}$ & 75 & 100 \\
\hline From shallow $(<25 \mathrm{~cm})$ to bedrock $(0)$ & 15.15 & 30.30 & 75.76 & & & \\
\hline From moderately shallow $(25-50 \mathrm{~cm})$ to shallow $(<25 \mathrm{~cm})$ & 15.15 & 30.30 & 75.76 & & & \\
\hline $\begin{array}{l}\text { From moderately deep }(50-100 \mathrm{~cm}) \text { to moderately shallow } \\
(25-50 \mathrm{~cm})\end{array}$ & 5.05 & 10.10 & 25.25 & 50.51 & 75.76 & 100.00 \\
\hline From deep $(100-150 \mathrm{~cm})$ to moderately deep $(50-100 \mathrm{~cm})$ & 3.03 & 6.06 & 15.15 & 30.30 & 45.45 & 60.61 \\
\hline From very deep $(>150 \mathrm{~cm})$ to deep $(100-150 \mathrm{~cm})$ & 2.16 & 4.33 & 10.82 & 21.65 & 32.47 & 43.29 \\
\hline \multicolumn{7}{|c|}{ Ambernath } \\
\hline \multirow[t]{2}{*}{ Soil depth class and change $(\mathrm{cm})$} & \multicolumn{6}{|c|}{$\begin{array}{c}\text { Amount of soil lost (\% of class) at erosion rates } \\
\left(\mathrm{t} \mathrm{ha}^{-1} \mathrm{yr}^{-1}\right)\end{array}$} \\
\hline & 5 & 10 & 25 & $\mathbf{5 0}$ & 75 & 100 \\
\hline From shallow $(<25 \mathrm{~cm})$ to bedrock $(0)$ & 15.50 & 31.01 & 77.52 & & & \\
\hline From moderately shallow $(25-50 \mathrm{~cm})$ to shallow $(<25 \mathrm{~cm})$ & 15.50 & 31.01 & 77.52 & & & \\
\hline $\begin{array}{l}\text { From moderately deep }(50-100 \mathrm{~cm}) \text { to moderately shallow } \\
(25-50 \mathrm{~cm})\end{array}$ & 5.17 & 10.34 & 25.84 & 51.68 & 77.52 & 100.00 \\
\hline From deep $(100-150 \mathrm{~cm})$ to moderately deep $(50-100 \mathrm{~cm})$ & 3.10 & 6.20 & 15.50 & 31.01 & 46.51 & 62.02 \\
\hline From very deep $(>150 \mathrm{~cm})$ to deep $(100-150 \mathrm{~cm})$ & 2.21 & 4.43 & 11.07 & 22.15 & 33.22 & 44.30 \\
\hline
\end{tabular}

Table 6. Tolerable soil loss $\left(\mathrm{t} \mathrm{ha}^{-1} \mathrm{yr}^{-1}\right)$ equivalent to $10 \% \mathrm{P}$ of the proportion of land downgraded and $>50 \%$ reduction in crop yield at low input level over 100 years in each tehsil of Palghar district

\section{Talsari and Palghar}

\begin{tabular}{|c|c|c|c|c|c|c|c|}
\hline \multirow{2}{*}{ Soil susceptibility } & \multicolumn{2}{|c|}{ Low $R m=25 \%$} & \multicolumn{2}{|c|}{ Intermediate $\mathbf{R m}=\mathbf{5 0} \%$} & \multicolumn{3}{|c|}{ High $\mathrm{Rm}=175 \%$} \\
\hline & Eqn.8 & Eqn.7 & Eqn.8 & Eqn. 7 & Eqn.8 & \multicolumn{2}{|c|}{ Eqn.7 } \\
\hline Shallow $(<25)$ & 0 & 0 & 0 & 0 & 0 & \multicolumn{2}{|c|}{0} \\
\hline Moderately shallow $(25-50)$ & 3.00 & 63 & 3.00 & 33 & 3.00 & \multicolumn{2}{|c|}{11.57} \\
\hline Moderately deep (50-100) & 9.00 & 63 & 9.00 & 33 & 9.00 & \multicolumn{2}{|c|}{11.57} \\
\hline Deep $(100-150)$ & 15.00 & 63 & 15.00 & 33 & 15.00 & \multicolumn{2}{|c|}{11.57} \\
\hline Very deep $(>150)$ & 21.00 & 63 & 21.00 & 33 & 21.00 & \multicolumn{2}{|c|}{11.57} \\
\hline \multicolumn{8}{|c|}{ Dahanu } \\
\hline \multirow{2}{*}{ Soil susceptibility } & \multicolumn{3}{|c|}{ Low $R m=25 \%$} & \multicolumn{2}{|c|}{ Intermediate $\mathbf{R m}=\mathbf{5 0} \%$} & \multicolumn{2}{|c|}{ High $R m=175 \%$} \\
\hline & Eqn.8 & & Eqn.7 & Eqn. 8 & Eqn.7 & Eqn.8 & Eqn.7 \\
\hline Shallow $(<25)$ & 0 & & 0 & 0 & 0 & 0 & 0 \\
\hline Moderately shallow (25-50) & 3.05 & & 64 & 3.05 & 33.5 & 3.05 & 11.71 \\
\hline Moderately deep (50-100) & 9.15 & & 64 & 9.15 & 33.5 & 9.15 & 11.71 \\
\hline Deep $(100-150)$ & 15.25 & & 64 & 15.25 & 33.5 & 15.25 & 11.71 \\
\hline Very deep $(>150)$ & 21.35 & & 64 & 21.35 & 33.5 & 21.35 & 11.71 \\
\hline
\end{tabular}




\begin{tabular}{|c|c|c|c|c|c|c|}
\hline \multicolumn{7}{|c|}{ Vasai } \\
\hline \multirow{2}{*}{ Soil susceptibility } & \multicolumn{2}{|c|}{ Low $\operatorname{Rm}=25 \%$} & \multicolumn{2}{|c|}{ Intermediate $\mathbf{R m}=\mathbf{5 0} \%$} & \multicolumn{2}{|c|}{ High Rm=175\% } \\
\hline & Eqn.8 & Eqn.7 & Eqn. 8 & Eqn.7 & Eqn. 8 & Eqn.7 \\
\hline Shallow $(<25)$ & 0 & 0 & 0 & 0 & 0 & 0 \\
\hline Moderately shallow (25-50) & 3.25 & 68 & 3.25 & 35.50 & 3.25 & 12.29 \\
\hline Moderately deep (50-100) & 9.75 & 68 & 9.75 & 35.50 & 9.75 & 12.29 \\
\hline Deep $(100-150)$ & 16.25 & 68 & 16.25 & 35.50 & 16.25 & 12.29 \\
\hline Very deep $(>150)$ & 22.75 & 68 & 22.75 & 35.50 & 22.75 & 12.29 \\
\hline \multicolumn{7}{|c|}{ Vada } \\
\hline \multirow{2}{*}{ Soil susceptibility } & \multicolumn{2}{|c|}{ Low $R m=25 \%$} & \multicolumn{2}{|c|}{ Intermediate $\mathrm{Rm}=50 \%$} & \multicolumn{2}{|c|}{ High $\mathrm{Rm}=175 \%$} \\
\hline & Eqn.8 & Eqn.7 & Eqn.8 & Eqn.7 & Eqn.8 & Eqn.7 \\
\hline Shallow $(<25)$ & 0 & 0 & 0 & 0 & 0 & 0 \\
\hline Moderately shallow (25-50) & 3.05 & 64 & 3.05 & 33.5 & 3.05 & 11.71 \\
\hline Moderately deep (50-100) & 9.45 & 64 & 9.15 & 33.5 & 9.15 & 11.71 \\
\hline Deep (100-150) & 15.25 & 64 & 15.25 & 33.5 & 15.25 & 11.71 \\
\hline Very deep $(>150)$ & 21.35 & 64 & 21.35 & 33.5 & 21.35 & 11.71 \\
\hline
\end{tabular}

Javhar and Mokhada

\begin{tabular}{lcccccc}
\hline \multirow{2}{*}{ Soil susceptibility } & \multicolumn{2}{c}{ Low $\mathbf{R m}=\mathbf{2 5} \boldsymbol{\%}$} & \multicolumn{2}{c}{ Intermediate $\mathbf{R m}=\mathbf{5 0} \%$} & \multicolumn{2}{c}{ High $\mathbf{R m}=\mathbf{1 7 5} \mathbf{\%}$} \\
\cline { 2 - 7 } & Eqn. 8 & Eqn.7 & Eqn.8 & Eqn.7 & Eqn.8 & Eqn.7 \\
\hline Shallow $(<25)$ & 0 & 0 & 0 & 0 & 0 & 0 \\
Moderately shallow $(25-50)$ & 3.20 & 67 & 3.20 & 35 & 3.20 & 12.14 \\
Moderately deep (50-100) & 9.60 & 67 & 9.60 & 35 & 9.60 & 12.14 \\
Deep (100-150) & 16.00 & 67 & 16.00 & 35 & 16.00 & 12.14 \\
Very deep $(>150)$ & 22.40 & 67 & 22.40 & 35 & 22.40 & 12.14 \\
\hline
\end{tabular}

Vikramgad

\begin{tabular}{lcccccc}
\hline \multirow{2}{*}{ Soil susceptibility } & \multicolumn{2}{c}{ Low $\mathbf{R m}=\mathbf{2 5} \%$} & \multicolumn{2}{c}{ Intermediate $\mathbf{R m}=\mathbf{5 0} \%$} & \multicolumn{2}{c}{ High $\mathbf{R m}=\mathbf{1 7 5} \%$} \\
\cline { 2 - 7 } & Eqn.8 & Eqn.7 & Eqn.8 & Eqn.7 & Eqn.8 & Eqn.7 \\
\hline Shallow $(<25)$ & 0 & 0 & 0 & 0 & 0 & 0 \\
Moderately shallow $(25-50)$ & 3.08 & 64.5 & 3.08 & 33.75 & 3.08 & 11.79 \\
Moderately deep $(50-100)$ & 9.23 & 64.5 & 9.23 & 33.75 & 9.23 & 11.79 \\
Deep $(100-150)$ & 15.38 & 64.5 & 15.38 & 33.75 & 15.38 & 11.79 \\
Very deep $(>150)$ & 21.53 & 64.5 & 21.53 & 33.75 & 21.53 & 11.79 \\
\hline
\end{tabular}


Table 7. Tolerable soil loss $\left(\mathrm{tha}^{-1} \mathrm{yr}^{-1}\right)$ equivalent to $10 \% \mathrm{P}$ of the proportion of land downgraded and $>50 \%$ reduction in crop yield at low input level over 100 years in each tehsils of Thane district

\begin{tabular}{|c|c|c|c|c|c|c|}
\hline \multicolumn{7}{|c|}{ Thane and Bhiwandi } \\
\hline \multirow{2}{*}{ Soil susceptibility } & \multicolumn{2}{|c|}{ Low $R m=25 \%$} & \multicolumn{2}{|c|}{ Intermediate $\mathbf{R m}=\mathbf{5 0} \%$} & \multicolumn{2}{|c|}{ High $R m=175 \%$} \\
\hline & Eqn.8 & Eqn.7 & Eqn. 8 & Eqn.7 & Eqn.8 & Eqn.7 \\
\hline Shallow $(<25)$ & 0 & 0 & 0 & 0 & 0 & 0 \\
\hline Moderately shallow (25-50) & 3.13 & 65.5 & 3.13 & 34.25 & 3.13 & 11.93 \\
\hline Moderately deep (50-100) & 9.38 & 65.5 & 9.38 & 34.25 & 9.38 & 11.93 \\
\hline Deep (100-150) & 15.63 & 65.5 & 15.63 & 34.25 & 15.63 & 11.93 \\
\hline Very deep $(>150)$ & 21.88 & 65.5 & 21.88 & 34.25 & 21.88 & 11.93 \\
\hline \multicolumn{7}{|c|}{ Shahapur and Murbad } \\
\hline \multirow{2}{*}{ Soil susceptibility } & \multicolumn{2}{|c|}{ Low $\mathrm{Rm}=25 \%$} & \multicolumn{2}{|c|}{ Intermediate $\mathbf{R m}=\mathbf{5 0} \%$} & \multicolumn{2}{|c|}{ High $R m=175 \%$} \\
\hline & Eqn.8 & Eqn.7 & Eqn. 8 & Eqn.7 & Eqn. 8 & Eqn.7 \\
\hline Shallow $(<25)$ & 0 & 0 & 0 & 0 & 0 & 0 \\
\hline Moderately shallow (25-50) & 3.18 & 66.5 & 3.18 & 34.75 & 3.18 & 12.07 \\
\hline Moderately deep (50-100) & 9.53 & 66.5 & 9.53 & 34.75 & 9.53 & 12.07 \\
\hline Deep $(100-150)$ & 15.88 & 66.5 & 15.88 & 34.75 & 15.88 & 12.07 \\
\hline Very deep $(>150)$ & 22.23 & 66.5 & 22.23 & 34.75 & 22.23 & 12.07 \\
\hline
\end{tabular}

Kalyan and Ulhasnagar

\begin{tabular}{|c|c|c|c|c|c|c|}
\hline \multirow{2}{*}{ Soil susceptibility } & \multicolumn{2}{|c|}{ Low $R m=25 \%$} & \multicolumn{2}{|c|}{ Intermediate $\mathbf{R m}=\mathbf{5 0} \%$} & \multicolumn{2}{|c|}{ High $R m=175 \%$} \\
\hline & Eqn.8 & Eqn.7 & Eqn. 8 & Eqn.7 & Eqn.8 & Eqn.7 \\
\hline Shallow $(<25)$ & 0 & 0 & 0 & 0 & 0 & 0 \\
\hline Moderately shallow (25-50) & 3.30 & 69 & 3.08 & 36 & 3.08 & 12.43 \\
\hline Moderately deep (50-100) & 9.90 & 69 & 9.23 & 36 & 9.23 & 12.43 \\
\hline Deep $(100-150)$ & 16.50 & 69 & 15.38 & 36 & 15.38 & 12.43 \\
\hline Very deep $(>150)$ & 23.10 & 69 & 21.53 & 36 & 21.53 & 12.43 \\
\hline \multicolumn{7}{|c|}{ Ambernath } \\
\hline \multirow{2}{*}{ Soil susceptibility } & \multicolumn{2}{|c|}{ Low $R m=25 \%$} & \multicolumn{2}{|c|}{ Intermediate $\mathbf{R m}=\mathbf{5 0} \%$} & \multicolumn{2}{|c|}{ High $R m=175 \%$} \\
\hline & Eqn.8 & Eqn.7 & Eqn. 8 & Eqn.7 & Eqn.8 & Eqn.7 \\
\hline Shallow $(<25)$ & 0 & 0 & 0 & 0 & 0 & 0 \\
\hline Moderately shallow (25-50) & 3.23 & 67.5 & 3.23 & 35.25 & 3.23 & 12.21 \\
\hline Moderately deep (50-100) & 9.68 & 67.5 & 9.68 & 35.25 & 9.68 & 12.21 \\
\hline Deep $(100-150)$ & 16.13 & 67.5 & 16.13 & 35.25 & 16.13 & 12.21 \\
\hline Very deep $(>150)$ & 22.58 & 67.5 & 22.58 & 35.25 & 22.58 & 12.21 \\
\hline
\end{tabular}


Tolerable soil loss $\left(\mathrm{t} \mathrm{ha}^{-1} \mathrm{yr}^{-1}\right)$ for moderately deep soil was obtained as by taking average of all the tehsil-wise tolerable soil losses.

Average tolerable soil loss for

Palghar district $=9.36 \mathrm{t} \mathrm{ha}^{-1} \mathrm{yr}^{-1}$

Average tolerable soil loss for

Thane district $=9.61 \mathrm{t} \mathrm{ha}^{-1} \mathrm{yr}^{-1}$

Total annual soil loss in Palghar and Thane districts

In Palghar and Thane districts, total six classes

of soil erosion were identified. Taking the median values of the soil erosion range, the total soil lost under different erosion classes was estimated (Table 8). Topsoil formation at the rate of $1 \mathrm{~mm}^{-e^{-1}}$ was equivalent to an annual addition of 13.3 tonnes ha $^{-1}$, taking into account the weight of a hectare furrow slice $(15 \mathrm{~cm}$ depth) soil as $2.2 \times 10^{6} \mathrm{~kg}$ (Bhattacharya et al. 2007). Since, Palghar and Thane districts represent a tropical wet climate; the soil formation rate of $2.0 \mathrm{~mm}$ should be equivalent to an annual addition of $\left(2.2 \times 10^{6} / 150\right) \times 2.0=29 \mathrm{t} \mathrm{ha}^{-1}$ soil. Hence, an annual addition of 29 tonnes soil to one hectare of land was considered for the present study.

Table 8. Severity of annual soil loss with areal extent in Palghar and Thane districts

\begin{tabular}{|c|c|c|c|c|c|}
\hline \multirow[b]{2}{*}{ Soil erosion class } & \multirow[b]{2}{*}{$\underset{\left(t h^{-1} \mathrm{yr}^{-1}\right)}{\text { Range }}$} & \multicolumn{2}{|c|}{ Palghar district } & \multicolumn{2}{|c|}{ Thane district } \\
\hline & & Area (ha) & $\begin{array}{c}\text { Soil loss } \\
\text { (million } \\
\text { tonnes) } \mathrm{yr}^{-1}\end{array}$ & Area (ha) & $\begin{array}{l}\text { Soil loss } \\
\text { (million } \\
\text { tonnes) } \mathrm{yr}^{-1}\end{array}$ \\
\hline Slight & $0-5$ & 9378.09 & 0.02 & 12264.55 & 0.03 \\
\hline Moderate & $5-10$ & 21381.82 & 0.16 & 26154.51 & 0.20 \\
\hline Moderately severe & $10-20$ & 48625.69 & 0.73 & 76167.39 & 1.14 \\
\hline Severe & $20-40$ & 251709.23 & 7.55 & 170514.6 & 5.12 \\
\hline Very severe & $40-80$ & 171054.44 & 10.26 & 121478.7 & 7.29 \\
\hline Extremely severe & $>80$ & 26642.43 & 2.66 & 12800.28 & 1.28 \\
\hline Total & - & 528791.70 & 21.39 & 419380.1 & 15.05 \\
\hline Effective soil loss & - & - & 20.48 & - & 13.68 \\
\hline
\end{tabular}

The annual loss of soil has been estimated to 21.39 million tonnes every year for Palghar district and 15.05 million tonnes every year for Thane district (Table 8). The effective soil loss has been found to be about 20.48 $(7.55+10.26+2.66)$ million tonnes every year for Palghar district and about $13.68(5.12+7.29+1.28)$ million tonnes every year for Thane district.

\section{Estimation of Conservation Practice Factor (P)}

The soil conservation need was estimated as the protection factor $(\mathrm{P})$ when lands are not under any conservation programmes. The average rate of erosion covers both the cultivated and uncultivated parts of the crop and fallow period cycle, but the soil conservation measures described only applied and maintained in the cultivated part of the cycle. For Palghar and Thane districts, different crop and fallow cycles of 4 to 10 years periods were tested to reduce the soil loss below the tolerable limit and get maximum crop years.

Out of 4 to 10 years crop cycles, 7 years crop cycle gave maximum crop years and minimum conservation practice factor to keep soil loss within the tolerable limit (Table 9). The total soil loss over 7 years crop cycle was $93 \mathrm{t} \mathrm{ha}^{-1}$. The tolerable soil losses for moderately deep soil were 9.36 and $9.61 \mathrm{t} \mathrm{ha}^{-1} \mathrm{yr}^{-1}$ for Palghar and Thane districts, respectively.

The reductions in soil loss were estimated for all tehsils of Palghar and Thane districts, e.g. for Vada tehsil of Palghar district the required soil loss reduction was $26.85 \mathrm{t} \mathrm{ha}^{-1}$ (93-66.15 $\mathrm{t} \mathrm{ha}^{-1}$ ) (Table 10). In land under cultivation, the total soil loss over 5 years was $85 \mathrm{t} \mathrm{ha}^{-1}$ $(12+18+25+12+18) \mathrm{t} \mathrm{ha}^{-1}$. Therefore, the estimated conservation practice factor $(\mathrm{P})$ was $0.32(26.85 / 85)$ 
(Table 10). Thus, conservation practice factors $(\mathrm{P})$ were calculated for all tehsils of Palghar and Thane districts (Table 10 and 11). The average conservation practice factor (P) for Palghar district was 0.32 and 0.30 for Thane district. Tehsil-wise conservation practice factors maps for Palghar and Thane districts were prepared shown in figs. 11 and 12 .

Table 9. Soil loss values over 7 years (for moderately deep soils)

\begin{tabular}{|c|c|c|c|}
\hline \multirow{2}{*}{ Year } & \multirow{2}{*}{ Land use } & \multicolumn{2}{|c|}{ Soil loss $\left(\mathrm{t} \mathrm{ha}^{-1}\right)$} \\
\hline & & Annual & Total \\
\hline 1 & Crop- $1^{\text {st }}$ year & 12 & 12 \\
\hline 2 & Crop- $2^{\text {nd }}$ year & 18 & 18 \\
\hline 3 & Fallow & 4 & 25 \\
\hline 4 & Crop- $3^{\text {rd }}$ year & 25 & 4 \\
\hline 5 & Crop- $1^{\text {st }}$ year & 12 & 12 \\
\hline 6 & Crop- $2^{\text {nd }}$ year & 18 & 18 \\
\hline 7 & Fallow & 4 & 4 \\
\hline Total soil loss over 7 years & & & 93 \\
\hline
\end{tabular}

Table 10. Estimation of tolerable soil loss rate (over 7 years) and conservation need ( $\mathrm{P}$ factor) of Palghar district (for moderately deep soils)

\begin{tabular}{lccc}
\hline Tehsils & $\begin{array}{c}\text { Tolerable rate of soil loss } \\
\left(\mathbf{t ~ h a}^{-\mathbf{1}}\right)\end{array}$ & $\begin{array}{c}\text { Soil loss Reduction } \\
\left(\mathbf{t ~ h a ~}^{\mathbf{- 1}}\right)\end{array}$ & $\begin{array}{c}\text { Concentration Need } \\
(\mathbf{P} \text { factor })\end{array}$ \\
\hline Vada & 66.15 & 26.85 & 0.32 \\
Javhar & 67.20 & 25.80 & 0.30 \\
Vasai & 68.25 & 24.75 & 0.29 \\
Talsari & 63.00 & 30.00 & 0.35 \\
Dahanu & 64.05 & 28.95 & 0.34 \\
Palghar & 63.00 & 30.00 & 0.35 \\
Vikramgad & 64.58 & 28.43 & 0.33 \\
Mokhada & 67.20 & 25.80 & 0.30 \\
& & Average & $\mathbf{0 . 3 2}$ \\
\hline
\end{tabular}

Table 11. Estimation of tolerable soil loss rate (over 7 years) and conservation need ( $\mathrm{P}$ factor) of Thane district (for moderately deep soils)

\begin{tabular}{lccc}
\hline Tehsils & Tolerable rate of soil loss $\left(\mathbf{t ~ h a}^{\mathbf{- 1}}\right)$ & $\begin{array}{c}\text { Soil loss Reduction } \\
\left(\mathbf{t ~ h a}^{\mathbf{1}}\right)\end{array}$ & $\begin{array}{c}\text { Concentration Need } \\
\text { (P factor) }\end{array}$ \\
\hline Kalyan & 69.30 & 23.70 & 0.28 \\
Bhiwandi & 65.63 & 27.38 & 0.32 \\
Shahapur & 66.68 & 26.33 & 0.31 \\
Murbad & 66.68 & 26.33 & 0.31 \\
Ambernath & 69.30 & 23.70 & 0.30 \\
Thane & 65.63 & 27.38 & 0.32 \\
Ulhasnagar & 69.30 & 23.70 & 0.28 \\
& & Average & $\mathbf{0 . 3 0}$ \\
\hline
\end{tabular}


Estimation of Average Annual Soil Loss after Conservation Measures

All the layers viz. R, K, LS, C and P (after conservation measures) were generated in ArcGIS 10.2 and were overlaid to estimate the annual soil loss (A) for the area. After adoption of soil and water conservation measures, the average annual soil loss were calculated as
9.02 $\mathrm{t} \mathrm{ha}^{-1} \mathrm{yr}^{-1}$ for Palghar district and $9 \mathrm{t} \mathrm{ha}^{-1} \mathrm{yr}^{-1}$ for Thane district. Maps of average annual soil losses for Palghar and Thane districts were prepared (Figs. 13 and 14).

The annual soil loss was categorized into six classes as slight, moderate, high, very high, severe, and very severe as per criteria given by Singh et al. (1992).

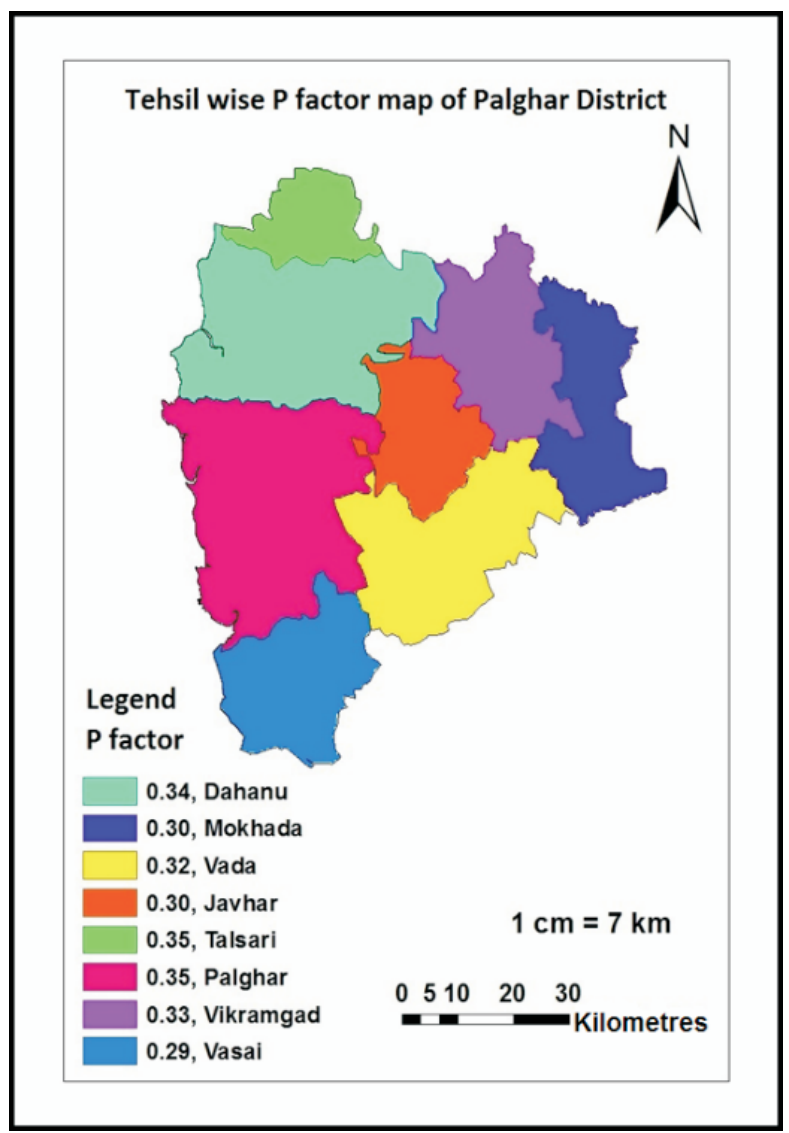

Fig. 11 Conservation practice factor $(\mathrm{P})$ map of different tehsils of Palghar district

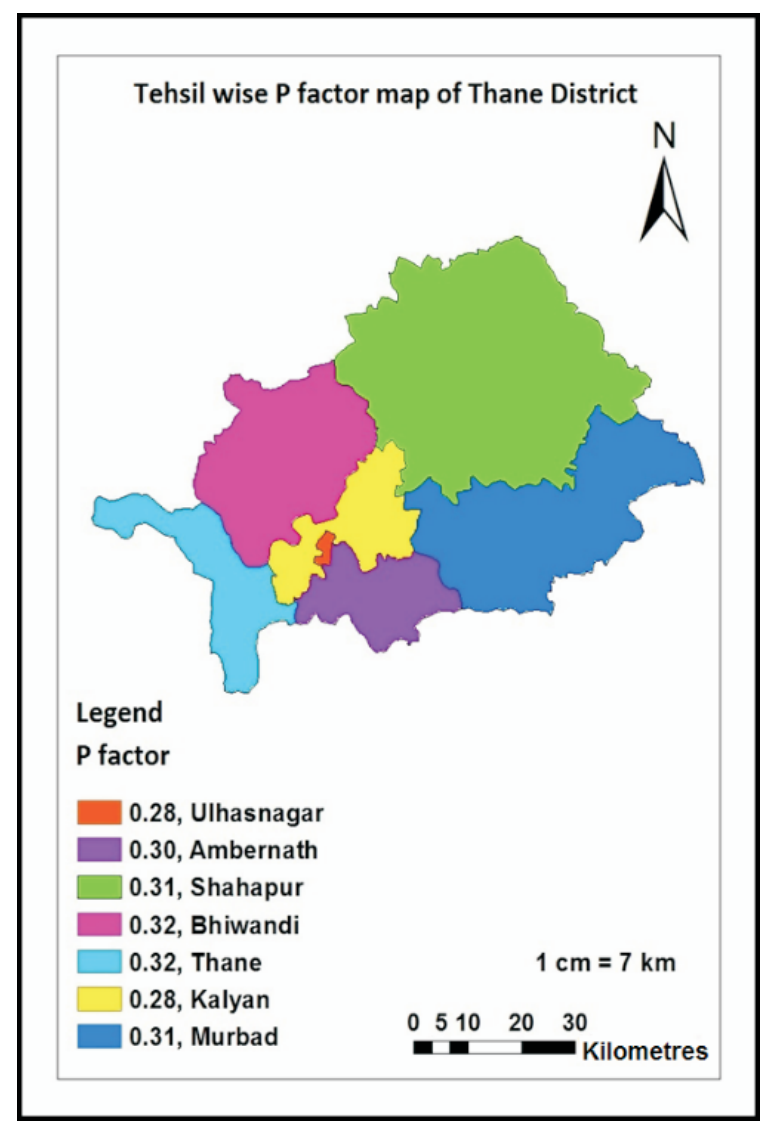

Fig. 12 Conservation practice factor $(\mathrm{P})$ map of different tehsils of Thane district

Table 12. Area under different classes of soil erosion after adoption of conservation measures in Palghar and Thane districts

\begin{tabular}{|c|c|c|c|c|c|}
\hline \multirow{2}{*}{ Soil erosion class } & \multirow{2}{*}{$\begin{array}{c}\text { Soil loss } \\
\left(\mathrm{t} \mathrm{ha}^{-1} \mathrm{yr}^{-1}\right)\end{array}$} & \multicolumn{2}{|c|}{ Palghar district } & \multicolumn{2}{|c|}{ Thane district } \\
\hline & & Area (ha) & $\%$ Area & Area (ha) & $\%$ Area \\
\hline Slight & $0-5$ & 191351.10 & 36.18 & 101844.20 & 24.29 \\
\hline Moderate & $5-10$ & 203625.40 & 38.50 & 188328.20 & 44.93 \\
\hline Moderately severe & $10-20$ & 102329.30 & 19.35 & 113186.10 & 27.00 \\
\hline Severe & $20-40$ & 22172.62 & 4.19 & 12755.90 & 3.04 \\
\hline Very severe & $40-80$ & $\begin{array}{c}9442.963 \\
527921.38\end{array}$ & 1.79 & 3081.51 & 0.74 \\
\hline
\end{tabular}


Due to adoption of soil and water conservation measures, soil loss of $9.02 \mathrm{t} \mathrm{ha}^{-1} \mathrm{yr}^{-1}$ will be expected to reduce from the Palghar district. About $38.50 \%$ area will be expected to come under moderate erosion class, $36.18 \%$ area under slight erosion class, $19.35 \%$ area under moderately severe erosion class, $4.19 \%$ area under severe erosion class and $1.79 \%$ area under very severe erosion class (Table 12). Similarly, soil loss of $9.38 \mathrm{t} \mathrm{ha}^{-1} \mathrm{yr}^{-1}$ will be expected to reduce from Thane district. About $44.93 \%$ area will be expected to come under moderate erosion class, $24.29 \%$ area under slight erosion class, $27 \%$ area under moderately severe erosion class $3.04 \%$ area under severe erosion class and $0.74 \%$ area under very severe erosion class (Table 12).

Tehsils-wise area under different classes of soil erosion after adoption of conservation measures of Palghar and Thane districts are shown in tables 13 and 14. Also maps of average annual soil loss of Palghar and Thane districts were prepared (Figs. 13 and 14)

Table 13. Tehsils-wise area under different classes of soil erosion after adoption of conservation measures in Palghar district

\begin{tabular}{|c|c|c|c|c|c|}
\hline \multicolumn{6}{|c|}{ Area under each class (ha) } \\
\hline$\frac{\text { Soil erosion class }\left(\mathrm{t} \mathrm{ha}^{-1} \mathrm{yr}^{-1}\right)}{\text { Tehsil }}$ & $\begin{array}{l}\text { Slight } \\
(0-5)\end{array}$ & $\begin{array}{l}\text { Moderate } \\
(5-10)\end{array}$ & $\begin{array}{c}\text { Moderately severe } \\
(\mathbf{1 0 - 2 0 )}\end{array}$ & $\begin{array}{l}\text { Severe } \\
(20-40)\end{array}$ & Very severe $(40-80)$ \\
\hline Talsari & 19246.16 & 17096.15 & 2059.56 & 10033.28 & 1820.55 \\
\hline Palghar & 76655.56 & 37081.96 & 37890.26 & 2306.98 & 118.39 \\
\hline Javhar & 34833.29 & 79211.26 & 987.68 & 1584.88 & 387.78 \\
\hline Dahanu & 57251.46 & 118418.20 & 24346.73 & 9179.72 & - \\
\hline Vasai & 35120.53 & 29714.87 & 7772.71 & 5909.59 & 6842.89 \\
\hline Mokhada & 30178.18 & 88538.60 & 1114.13 & 282.71 & 14.19 \\
\hline Vada & 28142.93 & 112860.60 & 31732.40 & 2700.63 & 287.58 \\
\hline Vikramgad & 22602.80 & 100112.30 & 18249.83 & 1923.76 & - \\
\hline Total & 304030.91 & 583032.72 & 124153.3 & 33921.55 & 9471.38 \\
\hline
\end{tabular}

Table 14. Tehsils-wise area under different classes of soil erosion after adoption of conservation measures in Thane district

\begin{tabular}{|c|c|c|c|c|c|}
\hline \multicolumn{6}{|c|}{ Area under each class (ha) } \\
\hline$\frac{\text { Soil erosion class }\left(\mathrm{tha}^{-1} \mathrm{yr}^{-1}\right)}{\text { Tehsil }}$ & $\begin{array}{l}\text { Slight } \\
(0-5)\end{array}$ & $\begin{array}{c}\text { Moderate } \\
(5-10)\end{array}$ & $\begin{array}{l}\text { Moderately } \\
\text { severe } \\
(10-20)\end{array}$ & $\begin{array}{l}\text { Severe } \\
(20-40)\end{array}$ & $\begin{array}{c}\text { Very severe } \\
\quad(\mathbf{4 0 - 8 0 )}\end{array}$ \\
\hline Ambernath & 65124.51 & 98296.81 & 4879.68 & 343.06 & 252.86 \\
\hline Bhiwandi & 70598.75 & 105684.60 & 8380.49 & 110.33 & 14.02 \\
\hline Kalyan & 67328.66 & 94098.60 & 2982.34 & 1895.78 & 83.15 \\
\hline Murbad & 10276.33 & 114968.50 & 43417.87 & 6962.29 & 2936.36 \\
\hline Shahapur & 16061.94 & 139327.60 & 84244.03 & 4494.23 & 109.41 \\
\hline Thane & 66369.62 & 12803.55 & 360.85 & - & - \\
\hline Ulhasnagar & 61626.90 & 91737.97 & 17.25 & 20.48 & - \\
\hline Total & 357386.71 & 656917.63 & 144282.51 & 13826.17 & 3395.8 \\
\hline
\end{tabular}




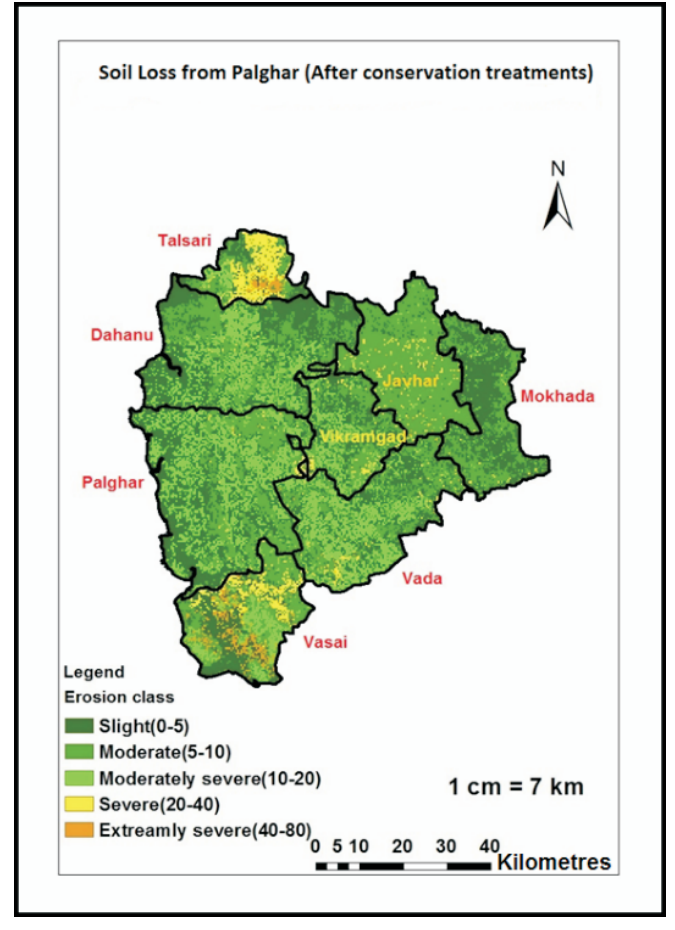

Fig.13 Average annual soil loss map of Palghar district after conservation measures

\section{Conclusions}

The average annual erosivity obtained for Palghar and Thane districts were 7,374.21 MJ-mm ha ${ }^{1} \mathrm{hr}^{-1} \mathrm{yr}^{-1}$ and 6,889.41 MJ-mm $\mathrm{ha}^{-1} \mathrm{hr}^{-1} \mathrm{yr}^{-1}$, respectively. Soil erodibility factor recorded for different locations of Palghar and Thane districts were 0.020 to 0.048 t-ha-hr $\mathrm{ha}^{-1} \mathrm{MJ}^{-1} \mathrm{~mm}^{-1}$ and 0.020 to $0.067 \mathrm{t}$-ha-hr ha ${ }^{-1} \mathrm{MJ}^{-1} \mathrm{~mm}^{-1}$, respectively. The values of LS factor for Palghar and Thane are found in the range of 1.92 to 4.19 and 1.47 to 3.88 , respectively. Crop management factor (C) values for Palghar and Thane districts ranged from 0.024 to 0.14 and 0.024 to 0.12 , respectively. The annual soil loss, before adoption of soil and water conservation measures, were estimated as $40.45 \mathrm{t} \mathrm{ha}^{-1} \mathrm{yr}^{-1}$ and $35.89 \mathrm{t}$ $\mathrm{ha}^{-1} \mathrm{yr}^{-1}$ for Palghar and Thane districts, respectively. The average tolerable soil loss estimated for moderately deep soils of Palghar and Thane district were $9.36 \mathrm{t}$ ha ${ }^{1} \mathrm{yr}^{-1}$ and $9.61 \mathrm{t}^{-1} \mathrm{yr}^{-1}$, respectively. The average conservation practice factors $(\mathrm{P})$ were estimated as 0.32 for Palghar district and 0.30 for Thane district. After adoption of soil and water conservation measures, the reductions in the average annual soil loss were estimated

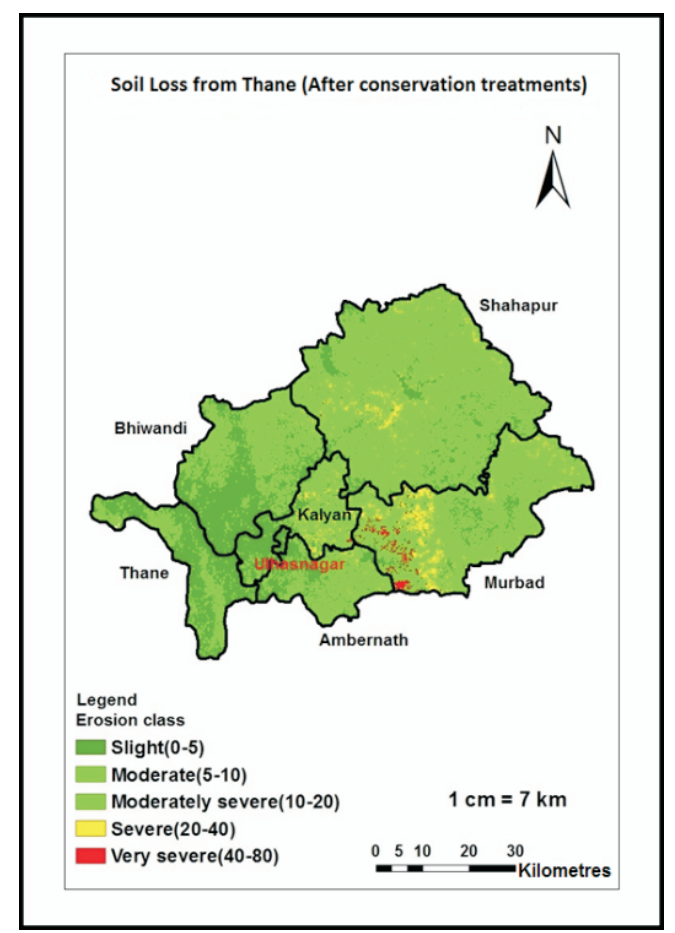

Fig.14 Average annual soil loss map of Thane district after conservation measures

as 9.02 $\mathrm{t} \mathrm{ha}^{-1} \mathrm{yr}^{-1}$ and $9.38 \mathrm{tha}^{-1} \mathrm{yr}^{-1}$ for Palghar and Thane districts respectively. Thus, soil erosion will be expected to reduce within the tolerable limit after adoption of soil and water conservation measures.

\section{References}

Bhattacharyya, T., Babu, R., Sarkar, D., Mandal, C., Dhyani, B. L. and Nagar, A. P. (2007). Soil loss and crop productivity model in humid subtropical India. Current Science 93, 13971403.

Kaur, R., Kumar, S. and Gurang, H. P. (2002). A pedotransfer function (PTF's) for estimating soil bulk density from basic soil data and its comparison with existing PTF's. Australian Journal of Soil Research 40, 847-857.

Renard, K. G., Foster, G. A., Weesies, D. K., McCool. and Yoder, D. C. (1997). Prediction of soil erosion by water: a guide to conservation planning with the revised universal soil loss equation (RUSLE), Agricultural Handbook 703, USDA, Washington, DC. 
Singh, G., Babu, R., Narain, P., Bhusan, L. S. and Abrol, I. P. (1992). Soil erosion rates in India. Journal of Soil and Water Conservation 47, 97-99.

Singh, R. and Phadke, V. S. (2006). Assessing soil loss by water erosion in Jamni River Basin, Bundelkhand region, India, adopting universal soil loss equation using GIS. Current Science 90,1431-1435.

Smith, D. D. (1941). Interpretation of soil conservation data for field use. Agriculture Engineering 22, 173-175.

Thawakar, S. M. (2014). Estimation of erodibility at selected locations in Konkan region. M. Tech. Thesis submitted to Department of Soil and Water Conservation Engineering, Dr. B. S. K. K. V. Dapoli. (unpublished)
Wischmeier, W. H. and Smith, D. D. (1965). Predicting rainfall erosion losses from cropland east of the Rocky Mountains. Handbook No. 282. Washington, DC, USDA.

Wischmeier, W. H. and Smith, D. D. (1978). Predicting rainfall erosion losses- A guide to conservation planning. Agricultural Handbook No. 537, USDA.

Yadav, M. B. and Mhatre, S. S. (2005). Synthesis of rainfall characteristics for predicting the erosivity pattern of Wakavali region. B. Tech. Thesis submitted to Department of Soil and Water and Water Conservation Engineering, Dr. B. S. K. K. V. Dapoli. (unpublished)

Received: August, 2018 Accepted: November, 2018 